\author{
Alina Walenia \\ Uniwersytet Rzeszowski \\ e-mail: alinawalenia@czta.onet.pl
}

\title{
MECHANIZMY KONTROLI WYKORZYSTANIA ŚRODKÓW UNII EUROPEJSKIEJ W PERSPEKTYWIE FINANSOWEJ 2014-2020
}

\section{CONTROL MECHANISMS IN THE PROCESS OF THE USE OF EUROPEAN UNION FUNDS IN THE FINANCIAL PERSPECTIVE 2014-2020}

DOI: $10.15611 / \mathrm{pn} .2019 .544 .11$

JEL Classification: A1, D8

Streszczenie: Celem funkcjonowania mechanizmów kontrolnych środków Unii Europejskiej (UE) jest weryfikacja wywiązywania się beneficjentów z warunków umowy o dofinansowanie projektu oraz prawidłowości prowadzenia odrębnej księgowości i sprawozdawczości dla tych środków. Postępowanie kontrolne obejmuje obszar zarządzania środkami, zakres uprawnień podmiotów zarządzających tymi środkami, sprawdza prawidłowość ich wydatkowania. Zakresem kontroli pozostaje także ocena rozwiązań przyjętych w ramach poszczególnych programów operacyjnych w odniesieniu do obowiązujących przepisów prawa UE i krajowego. Zadania w zakresie kontroli wykonują instytucje tworzące system zarządzania i kontroli środków UE w ramach poszczególnych programów operacyjnych oraz system instytucji kontrolnych państwa (Najwyższa Izba Kontroli, Regionalna Izba Obrachunkowa, Krajowa Administracja Skarbowa i Prezes Urzędu Zamówień Publicznych).

Słowa kluczowe: środki z budżetu UE, system zarządzania i kontroli, nieprawidłowości w procesie wykorzystania środków UE.

Summary: The aim of control mechanisms is to verify if beneficiaries have fulfilled the conditions of a project financing agreement and separate accounting and financial reporting standards for these funds. The control of the projects co-financed by the European Union concerns actions taken by various entities and in all phases of project implementation. The audit procedures include the area of funds management, the remit of the entities managing these financial resources. These procedures verify the regularity of spending these funds. The scope of control includes also the evaluation of solutions adopted within the framework of specific operational programmes in respect of the current EU and national laws. Tasks in the scope of control are completed by institutions constituting a system of management and control of EU financial resources within the framework of specific operational programmes and the system of state audit bodies (Supreme Chamber of Control, Regional Chamber of Account, National Tax Administration and the President of Public Procurement Office).

Keywords: financial resources from the EU budget, system of management and control, irregularities in the use of EU funds. 


\section{Wstęp}

Kontrole wydatkowania środków unijnych przeprowadzane są przez instytucję zarządzającą danym programem operacyjnym, instytucję certyfikującą oraz audytową. Zadaniem instytucji zarządzających poszczególnymi programami operacyjnymi jest przeprowadzanie kontroli dokumentów, m.in. sporządzanych raportów o postępie realizacji projektu oraz raportów końcowych. Drugi szczebel kontroli to instytucje certyfikujące, których zadaniem jest poświadczenie Komisji Europejskiej, iż wnioski o refundację wydatków są prawidłowe, wydatki właściwie zaksięgowane - zgodnie $\mathrm{z}$ zasadami prawa unijnego. Instytucje certyfikujące przekazują do Komisji Europejskiej wnioski o refundację po uprzednim upewnieniu się, że wydatki objęte zostały właściwymi kontrolami. Skuteczność systemu zarządzania i kontroli sprawdza krajowa instytucja audytowa, która przekazuje Komisji Europejskiej raport i opinię audytową [Rozporządzenie Parlamentu Europejskiego i Rady]. Za wykrywanie nieprawidłowości w wydatkowaniu funduszy unijnych odpowiedzialne są głównie państwa członkowskie, których zadaniem jest stworzenie skutecznego systemu kontroli środków UE. Ujawnianie nieprawidłowości i nadużyć finansowych to podstawowa działalność organów kontroli państwa, tj. Krajowej Administracji Skarbowej (KAS), NIK, Prezesa Urzędu Zamówień Publicznych (UZP), RIO.

Celem niniejszej publikacji jest analiza podstawowych zasad i form kontroli środków UE, obowiązujących w perspektywie finansowej 2014-2020. Zdiagnozowanie najczęściej występujących nieprawidłowości w wykorzystaniu środków UE, a także dokonanie oceny skuteczności działań organów kontroli w tym zakresie. Główna hipoteza badawcza sformułowana została następująco: wdrożenie sprawnego systemu kontroli środków $\mathrm{z}$ budżetu UE w Polsce przez instytucje zaangażowane w procedury kontroli i monitoringu ma istotny wpływ na ograniczenie nieprawidłowości w wykorzystaniu tych środków. Materiały źródłowe stanowią głównie przepisy prawne oraz dokumenty krajowe i UE dotyczące zarządzania środkami UE, w tym procesów kontroli. Podstawową metodą badawczą wykorzystaną do analizy materiału źródłowego była metoda dedukcji, służąca głównie do analizy aktów prawa unijnego i krajowego oraz dokumentów tworzonych przez krajowe instytucje systemu zarządzania i kontroli środków UE.

\section{System kontroli środków UE}

Zgodnie z przepisami rozporządzenia 1303/2013 [Rozporządzenie Parlamentu Europejskiego i Rady] w Polsce w perspektywie finansowej 2014-2020 można wyróżnić trzy funkcjonujące niezależnie systemy kontroli środków UE (rys. 1):

- Kontrole stanowiące kompetencję instytucji zarządzającej.

- Kontrole wyrywkowe - czynności sprawdzające, przeprowadzane przez organ kontroli, który nie uczestniczy w systemie wdrażania programów operacyjnych 
i jest funkcjonalnie niezależny od instytucji zarządzającej, pośredniczącej lub wdrażającej. Organem wykonującym ww. kontrole w Polsce jest szef Krajowej Administracji Skarbowej (KAS), który realizuje kontrole za pomocą Izb Administracji Skarbowej. Szef KAS pełni funkcję instytucji audytowej.

- Kontrole wykonywane przez upoważnione instytucje UE oraz instytucje krajowe, które nie uczestniczą bezpośrednio we wdrażaniu funduszy strukturalnych (Komisja Europejska, Europejski Urząd ds. Zwalczania Nadużyć Finansowych oraz Europejski Trybunał Obrachunkowy). Natomiast podmiotami krajowymi uprawnionymi do kontroli środków UE są: Prezes Urzędu Zamówień Publicznych (w zakresie stosowania przepisów ustawy Prawo zamówień publicznych) oraz Najwyższa Izba Kontroli (m.in. w zakresie gospodarowania środkami UE stanowiącymi środki publiczne), Regionalna Izba Obrachunkowa (w zakresie gospodarowania środkami UE przez samorząd terytorialny). Szczególne miejsce zajmuje kontrola na zakończenie realizacji projektu, służąca sprawdzeniu kompletności dokumentów potwierdzających właściwą ścieżkę audytu w odniesieniu do danego projektu. Jest to specjalny rodzaj kontroli przeprowadzanej podczas weryfikacji ostatniego wniosku o płatność. W trakcie tej kontroli instytucja zarządzająca upewnia się, że posiada pełną dokumentację, która potwierdza realizację projektu. Pozytywny wynik kontroli powinien być warunkiem ostatecznego rozliczenia projektu oraz przekazania beneficjentowi płatności końcowej. Kontrola ta powinna również potwierdzać wykonanie rzeczowe projektu oraz osiągnięcie wskaźników i rezultatów planowanych w umowie o dofinansowanie.

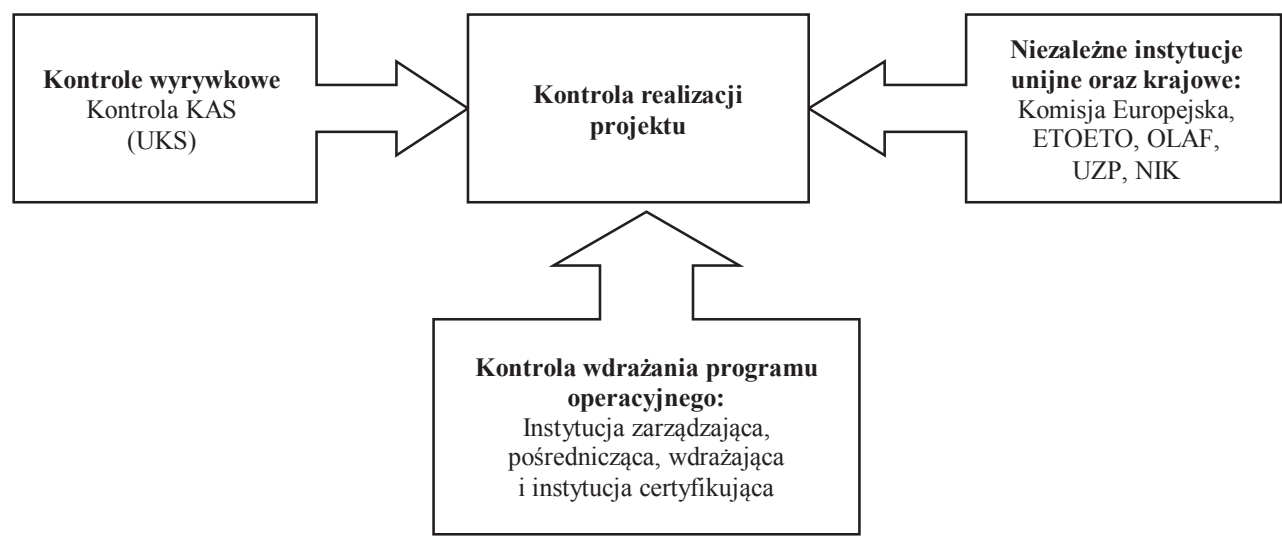

Rys. 1. Schemat kontroli realizacji projektu współfinansowanego ze środków UE z przeznaczeniem na politykę spójności

Źródło: opracowanie własne.

Opracowane przez państwo członkowskie procedury kontroli środków UE powinny mieć dwie najważniejsze cechy: 
- skutecznie wykrywać nieprawidłowości przed dokonaniem płatności ze środków publicznych,

- nie utrudniać realizacji projektów przez beneficjentów.

Organy kontroli państwa prowadzą kontrole w celu wykrywania i usuwania błędów oraz nieprawidłowości w zarządzaniu programami operacyjnymi. Działania kontrolne mają także na celu usprawnienie wykorzystania środków UE [Srebro 2004].

\section{Nieprawidłowości w zakresie wykorzystania środków UE}

Kolejne perspektywy wdrażania środków unijnych wskazują, iż nawet najlepiej opracowane procedury kontroli nie wyeliminują ryzyka występowania nieprawidłowości. Potwierdzają to dane z lat 2010-2016, publikowane przez Ministra Finansów pełniącego funkcję instytucji płatniczej w zakresie środków z budżetu UE. Dane te wskazują, że kwota stwierdzonych nieprawidłowości stanowiła poniżej 2\% łącznej kwoty wydatkowanych środków UE w Polsce. Niewielki wskaźnik wykrytych nieprawidłowości informuje o pozytywnej ocenie funkcjonującego systemu kontroli i zarządzania środkami UE.

Największa ilość zgłoszonych do Komisji Europejskiej [MF 2016] nieprawidłowości dotyczyła wydatkowania środków w ramach Europejskiego Funduszu Rolnego na rzecz Rozwoju Obszarów Wiejskich i Europejskiego Funduszu Rozwoju Regionalnego. Z punktu widzenia instytucji zaangażowanych w system zarządzania i kontroli funduszy strukturalnych najistotniejsze jest, czy nieprawidłowość została wykryta przed wypłatą środków beneficjentowi, czy też po dokonaniu tej wypłaty. Oczywiście kryterium tego nie można odnieść do projektów, których system wypłaty dotacji unijnych polega na rozliczaniu przekazanych uprzednio beneficjentowi zaliczek. Z opracowań Ministerstwa Finansów wynika, że ponad 80\% stwierdzonych nieprawidłowości wykrytych zostało przed dokonaniem ich płatności. W celu zminimalizowania ryzyka nieprawidłowego wydatkowania środków z funduszy strukturalnych i Funduszu Spójności pomocne może okazać się przeanalizowanie typów nieprawidłowości, które odzwierciedlają najczęściej naruszane przepisy prawa. Najczęściej występującą nieprawidłowością (rys. 2) było naruszenie przepisów ustawy Prawo zamówień publicznych, a w szczególności:

- zasad konkurencji i upowszechniania informacji o zamówieniu,

- działań związanych z przygotowaniem dokumentacji (np. brak dokumentacji projektowej w chwili zamieszczenia ogłoszenia o zamówieniu publicznym, nieprzekazanie oferentom robót specyfikacji istotnych warunków zamówienia w terminie określonym w ustawie),

- wyboru najkorzystniejszej oferty.

Ujawnionym nadużyciem finansowym było fałszowanie dokumentów - działanie takie występuje w odniesieniu do wniosków o dofinansowanie projektu, w przypadku których beneficjenci przedstawiają nieprawdziwe dane lub załączają podrobione dokumenty uzupełniające (różnego typu oświadczenia, zaświadcze- 
nia). Tego typu działania traktowane są jako podejrzenia popełnienia oszustwa na szkodę budżetu UE. Problem stanowiły wydatki niekwalifikowalne - najczęściej wykrywane są przypadki finansowania przez beneficjentów działań, które nie są związane z realizacją przedsięwzięcia oraz nie zostały określone w umowie o dofinansowanie. W sytuacji stwierdzenia tego typu nieprawidłowości beneficjenci nie mogą liczyć na refundację wydatków ze środków unijnych. W przypadku końcowego rozliczenia oraz ostatecznego dokonania wszystkich płatności na rzecz beneficjenta podejmowane są czynności mające na celu egzekucję nieprawidłowo sfinansowanych działań. Występującą nieprawidłowością była także niepełna realizacja niektórych działań w ramach projektu, np. zakupu produktów lub wykonaniu robót. Sytuacja taka może zaistnieć, jeżeli wskaźniki produktu określone we wniosku o dofinansowanie projektu i sprawozdaniach z realizacji projektu nie są zgodne z rzeczywiście wykonanymi robotami lub dostarczonymi usługami. Takie przypadki traktowane są jako potwierdzenie przez beneficjenta nieprawdziwych informacji i w konsekwencji uznawane za działania mające na celu wyłudzenie dotacji, a więc popełnienie przestępstwa.

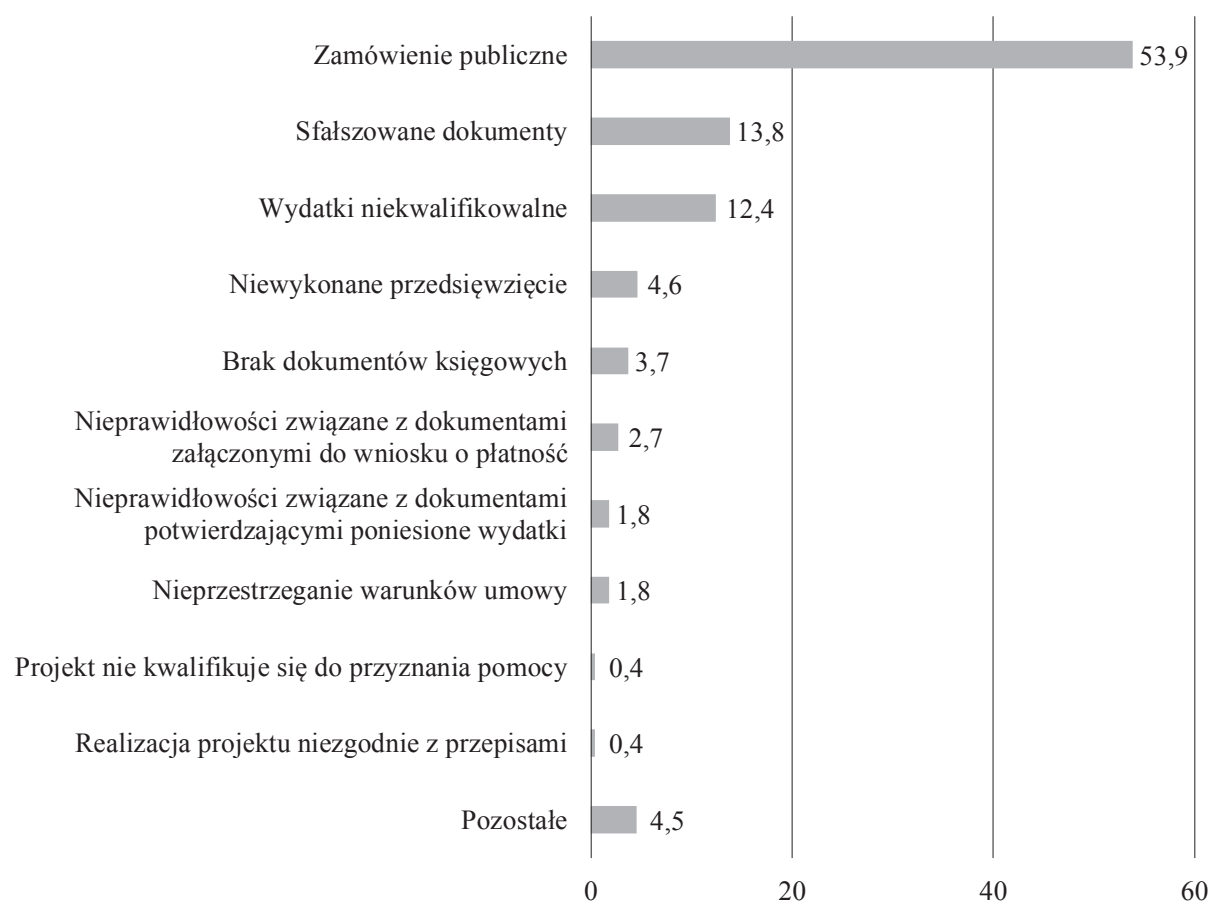

Rys. 2. Rodzaje zgłoszonych do Komisji Europejskiej nieprawidłowości dotyczących środków UE $(\mathrm{w} \%)$

Źródło: Dane Ministerstwo Finansów, Departament Certyfikacji i Poświadczeń Środków z UE (raporty i opracowania 2016). 
W procesie realizacji przedsięwzięć współfinansowanych ze środków UE można wskazać następujące przyczyny powstawania nieprawidłowości:

- nieznajomość przepisów prawnych, a w szczególności przepisów prawa zamówień publicznych oraz dokumentów dotyczących wdrażania programu operacyjnego,

- nieprzestrzeganie przez beneficjentów zasad określonych w umowie o dofinansowanie projektu,

- zmienność przepisów prawa,

- nierzetelność lub niedokładność przedkładanych przez beneficjenta dokumentów, sporządzanie na ostatnią chwilę sprawozdań z realizacji projektu oraz wniosków o płatność (brak dokumentacji, błędy rachunkowe).

Dane zgromadzone przez Ministra Finansów (rys. 3) potwierdzają, że najbardziej skutecznymi sposobami wykrywania nieprawidłowości w zakresie gospodarowania funduszami unijnymi są: kontrola na miejscu oraz wstępne czynności sprawdzające, tj. weryfikacja wniosków o dofinansowanie projektu oraz wniosków o płatność. Materiał empiryczny potwierdza, iż ponad $80 \%$ przypadków niewłaściwego wydatkowania środków unijnych jest wykrywana przez instytucje uczestniczące we wdrażaniu programów operacyjnych, tj. instytucje zarządzające, instytucje pośredniczące oraz instytucje wdrażające. System kontrolny państwa jest mało skuteczny w tym zakresie, organy kontroli państwa (kontrola skarbowa, NIK, RIO, Prezes Urzędu Zamówień Publicznych) wykrywają zaledwie 4\% nieprawidłowości.

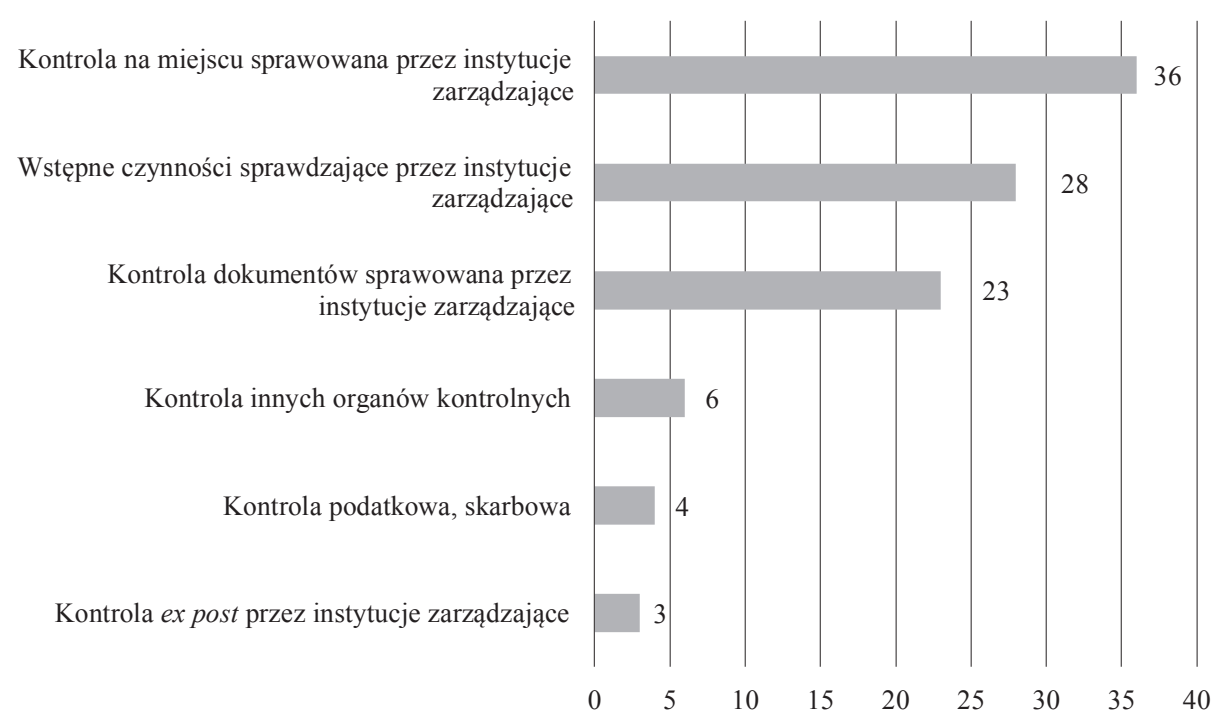

Rys. 3. Metody wykrywania nieprawidłowości w wykorzystaniu środków z budżetu UE (w \%)

Źródło: Dane Ministerstwo Finansów, Departament Certyfikacji i Poświadczeń Środków z UE (raporty i opracowania 2016). 
Wykrycie nieprawidłowości przez instytucje kontrolujące powoduje zastosowanie sankcji określonych $\mathrm{w}$ przepisach prawa oraz umowie o dofinansowanie projektu (np. zwrot dotychczas otrzymanych środków, wykluczenie z otrzymania dofinansowania). Ponadto państwo członkowskie jest zobowiązane do poinformowania Komisji Europejskiej (Europejskiego Urzędu ds. Zwalczania Nadużyć Finansowych OLAF) o występowaniu nieprawidłowości w realizacji projektu oraz o podmiotach, których działania doprowadziły do niewłaściwego wydatkowania środków unijnych [Chojna-Duch 2010].

\section{Zakończenie}

Analiza materiału źródłowego potwierdziła, że w Polsce wdrożony został sprawny systemu kontroli środków z budżetu UE przez instytucje zaangażowane w procedury kontroli i monitoringu. Sprawność systemu zarządzania i kontroli środków UE w ramach poszczególnych programów operacyjnych ma istotny wpływ na ograniczanie występowania nieprawidłowości. System ten polegał na wyodrębnieniu instytucji zaangażowanych $\mathrm{w}$ proces zarządzania środkami UE (instytucje zarządzające, pośredniczące, wdrażające, certyfikujące oraz instytucja audytowa) oraz ustanowieniu spójnego i zharmonizowanego zakresu zadań dla tych instytucji. Materiał empiryczny potwierdzał, iż w Polsce systemy zarządzania i kontroli ustanowione dla poszczególnych programów operacyjnych były skuteczne, ponieważ ponad $80 \%$ przypadków niewłaściwego wydatkowania środków unijnych zostało wykrytych przez instytucje uczestniczące we wdrażaniu programów operacyjnych, tj. instytucje zarządzające, instytucje pośredniczące oraz instytucje wdrażające. Skuteczność systemu kontroli, stworzonego przez organy państwa, oceniona została zdecydowanie słabiej, ponieważ ich udział w wykrywaniu nieprawidłowości wynosił ok. 4\%.

\section{Literatura}

Chojna-Duch E., 2010, Próba systematyzacji pojęć $i$ zadań z dziedziny kontroli i audytu wewnętrznego na podstawie ustawy o finansach publicznych, Kontrola Państwowa, nr 1.

Dziadek K., 2011, Kontrola jako narzędzie wykrywania nieprawidłowości w wykorzystaniu funduszy unijnych, Zeszyty Naukowe Uniwersytetu Szczecińskiego. Finanse. Rynki finansowe. Ubezpieczenia, 42.

Łacny J., 2010, Ochrona interesów finansowych Unii Europejskiej w dziedzinie polityki spójności, Wolters Kluwer, Warszawa.

Mazur J., Marcinkowski L., 2005, Kierunki możliwych zmian w systemie kontroli środków UE, Kontrola Państwowa, nr 4.

MF, 2016, Raport Ministra Finansów do Komisji Europejskiej w sprawie zgłaszanych nieprawidłowości w związku z wykorzystaniem środków UE, Ministerstwo Finansów, Warszawa.

Murzyn D., 2010, Polityka spójności Unii Europejskiej a proces zmniejszania dysproporcji w rozwoju gospodarczym Polski, C.H. Beck, Warszawa. 
Menkes J., 2007, Ramy instytucjonalne ochrony interesów finansowych WE - stan obecny, perspektywy rozwoju w przyszłości, [w:] Nowak C. (red.), Ochrona interesów finansowych rozszerzonej UE: nowe wyzwania, stare problemy, Wyd. SGH, Warszawa.

Piaszczyk A., 2006, System zarzadzania i kontroli środków z funduszy wspólnotowych. Rachunkowość, Audytor, nr 3.

Rozporządzenie Parlamentu Europejskiego i Rady (UE) nr 1303/2013 z 17 grudnia 2013 r. ustanawiające wspólne przepisy dotyczące Europejskiego Funduszu Rozwoju, Europejskiego Funduszu Społecznego, Funduszu Spójności, Europejskiego Funduszu Rolnego na rzecz Rozwoju Obszarów Wiejskich oraz Europejskiego Funduszu Morskiego i Rybackiego oraz ustanawiające przepisy ogólne dotyczące Europejskiego Funduszu Rozwoju Regionalnego, Europejskiego Funduszu Społecznego, Funduszu Spójności i Europejskiego Funduszu Morskiego i Rybackiego oraz uchylające rozporządzenie Rady (WE) nr 1083/2006 (Dz.Urz. UE L 347 z 20.12.2013).

Rydzewska-Włodarczyk M., 2011, Wybrane zagadnienia kontroli projektów wspólfinansowanych ze środków europejskich, Zeszyty Naukowe Uniwersytetu Szczecińskiego, nr 668.

Srebro B., 2004, Ochrona interesów finansowych Unii Europejskiej, Wyd. Wolters Kluwer, Warszawa.

Srebro B., 2006, Ochrona interesów finansowych Unii Europejskiej, [w:] Górski A., Sakowicz A. (red.), Zwalczanie przestępczości w Unii Europejskiej. Wspótpraca sądowa i policyjna w sprawach karnych, Wyd. Wolters Kluwer, Warszawa.

Wieczerzyńska B., 2016, Efektywność zamówień publicznych $w$ wymiarze prawnym, ekonomicznym i społecznym, Rocznik Administracji Publicznej, nr 2. 